\title{
Inhibition of Soluble Antigen-induced T Cell Proliferation by Warm-reactive Antibodies to Activated T Cells in Systemic Lupus Erythematosus
}

\author{
Akira Yamada and John B. Winfield \\ Department of Medicine, Division of Rheumatology and \\ Immunology, University of North Carolina, \\ Chapel Hill, North Carolina 27514
}

bstract. One of the fundamental immunologic characteristics of systemic lupus erythematosus (SLE) is a depressed $\mathrm{T}$ cell proliferative response to various specific and nonspecific stimuli. Both intrinsic cellulat defect(s) and inhibitory influences of humoral factors, e.g., antilymphocyte autoantibodies or immune complexes, have been postulated to underly this functional abnormality. Because patient serum can induce SLE-like $T$ cell dysfunction in normal cells, an extrinsic mechanism is probably responsible, but the nature and site of action of this humoral activity has not been defined. This laboratory recently described a novel antibody specific for activated T cells in SLE, which raised the possibility that suppression of $\mathrm{T}$ cell proliferation by SLE serum involved antibodies directed to surface determinants expressed during the process of activation. In experiments to examine this concept further, relatively warm-reactive antibodies to $T$ cell blasts were found to inhibit strongly the well-characterized $\mathrm{T}$ cell response to tetanus toxoid. These antibodies were distinct from conventional cold-reactive IgM antibodies to resting $T$ cells, which exhibited little inhibitory activity. Inhibition involved noncytotoxic effects on early activation events at the level of the responding $T$ cell, which markedly reduced the expression of receptors for interleukin 2 . Inhibitory effects on antigen-pulsed macrophages or on $\mathrm{T}$ cells already committed to proliferate were not demonstrable. Anti-T blast antibodies were characteristic of active SLE and were detected only occasionally in

Address reprint requests to Dr. Winfield.

Received for publication 26 March 1984 and in revised form 18 June 1984.

J. Clin. Invest.

(C) The American Society for Clinical Investigation, Inc. 0021-9738/84/12/1948/13 \$1.00

Volume 74, December 1984, 1948-1960 patients with inactive disease or non-SLE rheumatic disorders. Although the exact antigenic specificity was not identified, considerable evidence was obtained against the presence of antibodies to Ia and certain other surface determinants of functional relevance.

Our observations concerning the suppressive effects of anti-T blast antibodies in SLE serum on the $T$ cell response to tetanus toxoid should provide new insight into mechanisms of in vivo $\mathrm{T}$ cell dysfunction in this and other immunologic disorders.

\section{Introduction}

Many immune system functional abnormalities are recognized in systemic lupus erythematosus (SLE), ${ }^{1}$ including defective T cell proliferative response to various specific and nonspecific stimuli (1-4); impaired natural killer $(5,6)$, antibody-dependent $(7,8)$ and $T$ cell-mediated $(9,10)$ cytotoxicity; failure of suppression in multiple systems (11-15); increased numbers of spontaneously activated $B(13,16-18)$ and $T(19,20)$ cells; and decreased pokeweed mitogen-driven Ig production (13, 18). Certain evidence suggests that such functional abnormalities do not reflect an intrinsic defect(s) in lymphocytes or other cells, although this important issue has not been clarified fully. First, lymphocyte dysfunction usually is most evident in patients with active SLE and resolves during periods of disease remission. Second, many of these functional abnormalities can be reproduced in normal lymphocytes through effects of SLE serum or plasma. Finally, most investigators have either failed to demonstrate an intrinsic cellular defect or do not exclude participation of in vivo humoral effects, e.g., surface receptor modulation (21), which carry over to in vitro experiments.

1. Abbreviations used in this paper: $\beta_{2 \mathrm{~m}}, \beta_{2}$ microglobulin; $\mathrm{BRBC}$, bovine erythrocyte; $\mathrm{C}$, complement; $\mathrm{CH}_{50}$, total hemolytic complement activity; CLL, chronic lymphocytic leukemia; FITC, fluorescein isothiocyanate; $\left[{ }^{3} \mathrm{H}\right] \mathrm{TdR},\left[{ }^{3} \mathrm{H}\right]$ thymidine; IL-1, interleukin-1; IL-2, interleukin-2; PHA, phytohemagglutinin; PBMC, peripheral blood mononuclear cell; RA, rheumatoid arthritis; SLE, systemic lupus erythematosus. 
The available data strongly suggest that antilymphocyte antibodies contribute to certain types of abnormal lymphocyte function in SLE (reviewed in reference 22). The mechanisms by which antibody/lymphocyte interactions result in cellular dysfunction are not well understood, however. Uncertainty persists about the Ig class of the relevant antilymphocyte antibodies, and the requirement of antibodies for complement (C) fixation and cell lysis to exert their functional effects (23-26). In addition, several careful studies have failed to demonstrate an association between C-dependent lymphocytotoxic antibody activity and decreased $\mathrm{T}$ cell proliferation in different systems despite clear evidence for potent inhibitory activity in SLE serum $(21,27)$. Action of immune complexes or IgG antilymphocyte antibodies, which are relatively noncytotoxic in conventional complement-dependent assays (28), usually are invoked to explain such discrepancies.

Recently, this and other laboratories have described antibodies directed to $T$ cell activation antigens in SLE (29-31). The existence of such antibodies raises the possibility of an alternate mechanism for suppressive effects of SLE serum on $T$ cell function, i.e., interference with activation events per se by antibodies directed to surface determinants expressed during the process of activation. To examine this concept further, a series of experiments was performed to clarify the role of different types of antilymphocyte antibodies in inhibition of the well-characterized $T$ cell proliferative response to the soluble protein antigen, tetanus toxoid.

\section{Methods}

Patients and serum. Peripheral blood was obtained from 20 patients with SLE, 20 patients with rheumatoid arthritis (RA), 20 patients with miscellaneous rheumatic diseases (polymyositis, 3; scleroderma, 4; psoriatic arthritis, 3; osteoarthritis, 5; Reiter's syndrome, 2; and sarcoidosis, Sjogren's syndrome, and gout, 1 each), and 10 normal subjects. Patients with SLE met the revised diagnostic criteria of the American Rheumatism Association (32) and were unselected except for exclusion of those with prior transfusions or pregnancies. After separation from whole blood, serum was aliquoted and stored at $-70^{\circ} \mathrm{C}$. Each serum aliquot was heated at $56^{\circ} \mathrm{C}$ for $1 \mathrm{~h}$ immediately before use. SLE disease activity was assessed as described previously (33). A classification of active SLE was assigned if the patient exhibited one or more of the following clinical manifestations: arthralgia or arthritis, serositis, rash, oral ulcers, glomerulonephritis, pneumonitis, or central nervous system dysfunction that could not be attributed to causes other than SLE. Correlative serologic indices, which were not used to determine disease activity status, included total hemolytic complement activity $\left(\mathrm{CH}_{50}\right)$ and anti-double-stranded DNA detected by a Crithidea luciliae immunofluorescent assay.

Lymphocyte culture. Normal human peripheral blood mononuclear cells (PBMCs) were separated from heparinized venous blood by FicollHypaque flotation. After being washed, cells were cultured in volumes of $200 \mu \mathrm{l}$ at a density of $10^{6} \mathrm{cells} / \mathrm{ml}$ in RPMI 1640 medium (University of North Carolina Cancer Center, Chapel Hill, NC) containing $2 \mathrm{mM}$ glutamine, antibiotics, and $10 \%$ normal human $\mathrm{AB}$ serum (optimum concentration) in round-bottom tissue culture plates (Costar, Data Packaging, Cambridge, MA) in a humid 5\% $\mathrm{CO}_{2}, 95 \%$ air incubator. Phytohemagglutinin (PHA; Burroughs Wellcome Co., Research Triangle Park, NC) was used at a final concentration of 1 $\mu \mathrm{g} / \mathrm{ml}$, tetanus toxoid (Sate Biological Laboratories, Boston, MA) at $6.0 \mu \mathrm{g} / \mathrm{ml}$. Apparent proliferation was assessed by the addition of 1 $\mu \mathrm{Ci}\left[{ }^{3} \mathrm{H}\right]$ thymidine $\left(\left[{ }^{3} \mathrm{H}\right] \mathrm{TdR}\right)$ (ICN Pharmaceuticals, Inc., Irvine, CA) per well. $18 \mathrm{~h}$ later, radioactivity of cells from triplicate cultures was counted by liquid scintillation techniques. Maximum $\left[{ }^{3} \mathrm{H}\right] \mathrm{TdR}$ incorporation occurred after $3 \mathrm{~d}$ of culture for PHA and after $5 \mathrm{~d}$ of culture for tetanus toxoid. To obtain more activated $T$ cells for use in absorption experiments or as targets for assay of antilymphocyte antibody activity in disease sera, PBMCs were cultured as above in tissue culture flasks (Falcon Labware, Div. Becton, Dickinson, \& Co., Oxnard, CA). At the time of maximum blastogenesis (day 3 for PHA and day 5 for tetanus toxoid) cells were harvested, washed twice, and suspended at a density of $2 \times 10^{6} / \mathrm{ml}$ of medium for cytotoxicity assays, or $\geq 2 \times 10^{7} / \mathrm{ml}$ for absorption experiments.

To determine inhibitory activity of patient sera on mitogen- or antigen-stimulated lymphocyte proliferation, cells were cultured in a mixture of 5\% disease serum, or Ig fractions thereof, and 5\% standard normal $\mathrm{AB}$ serum to minimize variability. A final concentration of $5 \%$ was chosen for test sera because this was at or near the plateau for inhibition observed with 7.5 or $10 \%$. Percentage inhibition was calculated as peak incorporated counts per minute in cultures containing test serum divided by incorporated counts per minute in parallel cultures containing $10 \%$ standard normal AB serum. Each SLE serum was examined against tetanus toxoid- or PHA-stimulated PBMCs from three normal donors, which exhibited high proliferative responses to tetanus toxoid and PHA, i.e., $\sim 15,000-50,000$ and $\sim 25,000-75,000$ incorporated cpm/well, respectively. Background counts per minute in cultures not containing antigen or mitogen were $<1,000$. Variation in the degree of inhibition of proliferation with cells from different donors was comparable $( \pm 27 \%)$ to the precision of separate assays performed at different times with the same SLE serum/PBMC donor combinations, i.e., $\pm 25 \%$ of the mean throughout the range of inhibition values observed. There was no relationship between the degree of inhibition seen with a given SLE serum and the magnitude of the proliferative response induced in different PBMC donors. Therefore, inhibition data shown in Results represent experiments performed with cells from the same normal donor, which further reduced day-to-day experimental variability and optimized serum-serum comparisons of inhibitory activity. Percentage inhibition relative to control with sera from 10 normal subjects was negligible: $13 \pm 10 \%$ for tetanus toxoid-induced proliferation, and $8 \pm 11 \%$ for PHA-induced proliferation. For certain statistical analyses, limits for significant inhibition were established from these data as $>2$ SD above the mean values for the normal sera, i.e., $>33 \%$ for tetanus toxoid-containing cultures and $>30 \%$ for PHAcontaining cultures.

In certain experiments, plastic adherent peripheral mononuclear cells were pulsed with tetanus toxoid antigen before recombination with $T$ cells according to the technique of Geha et al. (34). In brief, plastic adherent macrophages ( $>85 \%$ esterase + ) were harvested with a rubber policeman, resuspended at a density of $1 \times 10^{5}$ cells $/ \mathrm{ml}$ in medium containing $6.0 \mu \mathrm{g} / \mathrm{ml}$ tetanus toxoid and either normal AB serum or SLE serum, and incubated for $18 \mathrm{~h}$ in $95 \%$ air, $5 \% \mathrm{CO}_{2}$ at $37^{\circ} \mathrm{C}$. The antigen-pulsed macrophages were then washed three times with RPMI 1640, recombined with $2 \times 10^{5} \mathrm{~T}$ cells ( $<1 \%$ esterase + ), purified by passage over nylon wool columns, and cultured in the usual fashion for $5 \mathrm{~d}$ with or without added SLE serum.

Cell fractionation. T cells were obtained as the nonadherent population after passage of PBMCs over nylon wool columns (Fenwall 
Laboratories, Berkeley, CA) according to the technique of Julius et al. (35). Nylon wool adherent cells, containing enriched numbers of B cells and monocytes, were recovered by wringing the nylon wool at cold temperatures. The B cells were further purified to be relatively free of monocytes by collection as the nonadherent population after a 2-h incubation in plastic Petri dishes. Monocytes were isolated directly from PBMCs by adherence to plastic. A variety of markers was used to assess the purity of these enriched cell populations: esterase staining of monocytes (36), and indirect immunofluorescence or complementdependent cytotoxic reactivity with monoclonal antibodies to Ia, IgM, and pan $\mathrm{T}$ determinants.

Special immunological reagents. Monoclonal antibodies included the following: L243 (anti-DR framework, American Type Culture Collection, Rockville, MD); anti-Tac (a generous gift from Dr. T. Waldmann, National Institutes of Health, Bethesda, MD); Leu-1, Leu-8, Leu-10, anti- $\beta_{2}$ microglobulin (anti- $\beta_{2 m}$; Becton-Dickinson \& Co., Sunnyvale, CA); OKT3, OKT4, OKT8, OKT11 (Ortho Diagnostics Raritan, NJ); 5E9 (antibody to transferrin receptor, a generous gift from Dr. B. Haynes (Duke University, Durham, NC); AA1 (anti-T blast, a generous gift from Dr. N. Chiorazzi, Rockefeller University, New York); and fluorescein isothiocyanate (FITC)-conjugated $\mathrm{F}(\mathrm{ab})_{2}$ goat anti-human IgM and FITC-rabbit anti-mouse IgG (Cappel Laboratories, Cochranville, PA). Chicken and rabbit anti-human Ia antibodies were gifts of Dr. N. Bernard (University of North Carolina, Chapel Hill, NC). Tetanus immune globulin was purchased from Cutter Laboratories, Inc. (Berkeley, CA). Purified human interleukin2 (IL-2; ENI lot 1608-13) was purchased from Electro-Nucleonics, Inc. (Silver Spring, MD).

Preparation of serum Ig fractions. IgG (7S) and IgM (19S) fractions were obtained from serum by sucrose density gradient ultracentrifugation using acid buffers (glycine-HCl, pH 3.0) as described previously (37). For certain experiments, IgG was prepared by DEAE cellulose chromatography and IgM was purified by affinity chromatography using anti-IgM-Sepharose 4B. After concentration of fractions to approximately the original serum volume, IgG and IgM concentrations were determined by nephelometry.

Microcytotoxicity. C-dependent microcytotoxicity was performed as previously described (28) with the use of modifications for detecting either cold- or warm-reactive antibodies. For detection of cold-reactive antibodies, $2 \times 10^{3}$ cells in a volume of $1 \mu \mathrm{l}$ were mixed with $1 \mu \mathrm{l}$ of serum, or Ig fraction thereof, in Terasaki plates (Falcon Labware) for $1 \mathrm{~h}$ at $15^{\circ} \mathrm{C}$. $5 \mu \mathrm{l}$ of prescreened rabbit $\mathrm{C}$ (Pel-Freez Biologicals, Rogers, AR) was then added for an additional 3-h incubation at $15^{\circ} \mathrm{C}$. Both stages were performed at $25^{\circ} \mathrm{C}$ for warm-reactive antibody assay. Cells were then stained with $5 \%$ eosin, fixed in $40 \%$ formalin, and examined by inverted phase-contrast microscopy. Cytotoxicity was expressed as the percentage of nonviable cells. For mitogen or antigenstimulated $T$ cell targets, anti- $T$ blast cytotoxicity was calculated as a percentage of total cells. In comparisons of antilymphocyte cytotoxicity and capacity of SLE serum to inhibit the tetanus toxoid response, PBMCs from the same normal donor were used in both assays. The percentage dead cells in assays with $\mathrm{C}$ alone or with $\mathrm{C}$ plus normal human $\mathrm{AB}$ serum was $<10 \%$. Sera giving $>10 \%$ cell killing were scored as positive for lymphocytotoxic antibody.

Monoclonal antibody rosettes and rosette inhibition. The monoclonal antibody rosette assay was performed according to Stocker et al. (38), by means of goat anti-mouse IgG-coated bovine erythrocytes (BRBCs; Biological Products, Winston-Salem, NC) as indicator cells. $200 \mu \mathrm{l}$ of $50 \%$ packed BRBCs and $100 \mu$ lof affinity-purified goat anti-mouse IgG $(800 \mu \mathrm{g} / \mathrm{ml}$, a gift from Dr. R. Eisenberg, University of North
Carolina) were mixed and followed by dropwise addition of $200 \mu$ l of $2.5 \mathrm{mM}$ chromic chloride (39). After incubation of the reaction mixture for $5 \mathrm{~min}$ at room temperature, anti-IgG-coated BRBCs were washed thoroughly and resuspended to 1\% in RPMI 1640 supplemented with $10 \%$ fetal calf serum (Hyclone, Logan, UT). $50 \mu$ l of a suspension of target lymphocytes $\left(2.5 \times 10^{5}\right)$ was incubated with $50 \mu \mathrm{l}$ of appropriate dilutions of monoclonal antibody for $30 \mathrm{~min}$ at $4^{\circ} \mathrm{C}$. After washing was done, target cells were suspended in RPMI 1640 containing 10\% fetal calf serum to a final density of $4 \times 10^{6} / \mathrm{ml}$, combined with an equal volume (usually $50 \mu \mathrm{l}$ ) of a $1 \%$ suspension of anti-mouse IgGcoated BRBCs, and centrifuged for $10 \mathrm{~min}$ at $200 \mathrm{~g}$ in small tubes (Fisher Scientific Co., Pittsburgh, PA). After incubation in ice water for $30 \mathrm{~min}$, the BRBC/lymphocyte mixture was gently resuspended, stained with Giemsa, and applied to glass microscope slides for microscopy to determine percentage rosette forming cells. At least 200 cells were counted in each assay. Cells used as targets included chronic lymphocytic leukemia (CLL) cells; normal resting $T$ cells purified through nylon wool columns; and T cell blasts activated by PHA. The following antibodies were studied in this assay: OKT3, OKT8, Leu-1, Leu-8 (anti-pan T); OKT4 (helper/inducer); OKT8 (suppressor/cytotoxic); L243 (anti-DR framework); Leu-10 (anti-DC/DS framework); anti-human $\beta_{2 m}$; and 5E9, anti-Tac, and AA1 (antibodies to activation neoantigens).

Antibodies in SLE sera to surface determinants recognized by the above monoclonal antibodies were sought in experiments to inhibit monoclonal antibody rosette formation. Target lymphocytes $\left(1 \times 10^{6}\right)$ were preincubated with $100 \mu \mathrm{l}$ of SLE or normal serum for $1 \mathrm{~h}$ at $4^{\circ} \mathrm{C}$ with frequent agitation. After pelleting and aspiration of serum, the cells were resuspended in the highest dilution of monoclonal antibody, giving near-maximal rosette formation, and rosettes were prepared and enumerated as described above. Inhibition was calculated as follows: percentage inhibition $=[(a-b) / b] \times 100$, where $a$ is the percentage rosettes with normal serum preincubation and $b$ is the percentage rosettes with SLE serum preincubation.

The major surface antigen(s) on T cells with which IgM antilymphocyte antibodies in SLE sera react can be modulated, i.e., exhibit decreased fluorescence intensity for SLE IgM staining (Yamada, A., M. Shaw, and J. B. Winfield, submitted for publication). This occurs spontaneously after brief incubations in medium at $37^{\circ} \mathrm{C}$ and is accelerated by SLE serum. Therefore, monoclonal antibody rosette inhibition also was examined in experiments where the target cells were preincubated with SLE serum at $37^{\circ} \mathrm{C}$ for $2 \mathrm{~h}$ before rosette assay.

Indirect immunofluorescence and flow cytometry. IgM and IgG antibody binding to $T$ cells in SLE serum was assessed by indirect immunofluorescence at $4^{\circ} \mathrm{C}$ using FITC-conjugated rabbit $\mathrm{F}\left(\mathrm{ab}^{\prime}\right)_{2}$ antibodies to human $\mu$ - or $\gamma$-chains as the second coat. Appropriate dilutions of mouse monoclonal antibodies and FITC-goat $F\left(a^{\prime}\right)_{2}$ antimouse IgG were used to determine known surface antigens. After they were stained, cells were kept at $4^{\circ} \mathrm{C}$ and either examined immediately or fixed with paraformaldehyde. Fluorescence intensity and percentage positive cells were determined by flow microfluorometry using an Epics V instrument (Coulter Electronics Inc., Hialeah, FL) equipped with argon laser (488 $\mathrm{nm})$, MDADS and EASY 1 computers, and appropriate software. Laser power, photomultiplier tube amplification, and gain settings were calibrated with fluorospheres (Coulter Electronics Inc.), and kept constant throughout the experimental run on a given lymphocyte preparation. In some experiments, attempts were made to block or modulate known determinants with SLE serum before staining with mouse monoclonal antibodies. 
Absorption and elution techniques. SLE sera or Ig fractions were exhaustively absorbed at $4^{\circ} \mathrm{C}\left(200 \mu \mathrm{l}\right.$ vol per $1 \times 10^{7}$ cells, repeated twice). Cell types used for absorption included resting nylon wool peripheral T cells; 3-d PHA- and 5-d tetanus toxoid-stimulated T blasts; and T and B cell lines (HSB and 2080, respectively; obtained from University of North Carolina Cancer Center Culture Facility). Completeness of absorption was confirmed by absence of C-dependent cytotoxicity against the absorbing cell type. To obtain eluates, $5 \times 10^{7}$ PHA-activated T cells were incubated with $500 \mu \mathrm{l}$ SLE serum at $4^{\circ} \mathrm{C}$ for $1 \mathrm{~h}$. After they were washed three times with cold buffer, the cells were suspended in medium and incubated for $1 \mathrm{~h}$ at $37^{\circ} \mathrm{C}$.

Statistical analysis. Statistical analyses of data were performed by Dr. Julio Singer (Biometrics Consulting Laboratory, University of North Carolina Department of Biostatistics). Because certain assumptions for the Chi-square test were not met, e.g., cell size $<5$, the twotail Fisher's exact test was used to examine the association of antilymphocyte antibody activity with capacity of SLE serum to inhibit the tetanus toxoid response. Pearson correlations also were computed in order to determine this relationship.

\section{Results}

In initial experiments, serum from patients with SLE or other rheumatic diseases was added on day 0 to normal human PBMCs cultured in the presence of tetanus toxoid or PHA. Sera from 11/20 unselected patients with SLE inhibited the optimum proliferative response of normal $T$ cells to tetanus toxoid, as assessed by incorporation of $\left[{ }^{3} \mathrm{H}\right] \mathrm{TdR}$ on day 5 of culture (Figs. 1 and 2). Most sera from patients with rheumatoid arthritis and a variety of other non-SLE rheumatic diseases were inactive in this regard.

Inhibition of the tetanus toxoid was not antigen specific, and it involved a saturable, noncytotoxic mechanism. Thus, nine sera also inhibited $T$ cell proliferation induced by diphtheria toxoid to a degree comparable to that observed with tetanus toxoid ( $62 \pm 30$ and $65 \pm 20 \%$, respectively). Reduction in incorporated $\left[{ }^{3} \mathrm{H}\right] \mathrm{TdR}$ reflected a true inhibition of proliferation rather than a shift in the time course of maximum response, as shown in kinetic experiments with six SLE sera. A plateau occurred with final serum concentrations between 5 and $10 \%$; e.g., in a typical experiment, inhibition with $5,7.5$, and $10 \%$ added SLE serum was 65,79 , and $81 \%$, respectively. Cell viability was not reduced in cultures containing SLE serum; i.e., $>95 \%$ of cells excluded trypan blue in inhibited and control cultures throughout the first $5 \mathrm{~d}$ of culture, with a decline to $85-90 \%$ on day 6 . Cell counts were the same in SLE serum and control cultures from day 0-day 4 but fell to $25-50 \%$ of control by day 6 . The titer of inhibitory activity was $<1: 16$.

Inhibition of PHA-stimulated $\mathbf{T}$ cell proliferation was observed with $8 / 20$ sera but usually was low (mean $=28 \%$ ), even though suboptimal concentrations of PHA were used. The capacity of sera to inhibit the tetanus toxoid response was not significantly associated with inhibition of the PHA response ( $P=0.09$ by two-tail Fisher's exact test), primarily because of the relatively larger number of sera $(n=4)$ that suppressed

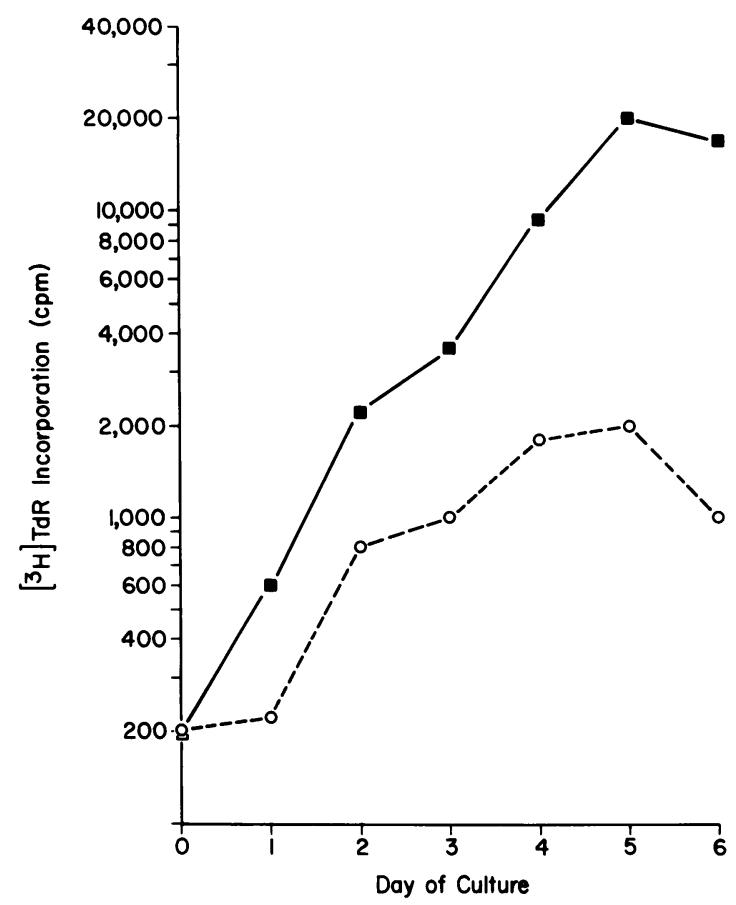

Figure 1. Kinetics of inhibition of tetanus toxoid-induced T cell proliferation by SLE serum. Cultures contained 5\% heat-inactivated SLE serum (O) or standard normal AB serum ( $(\mathbf{)})$ added on day 0. Data points represent mean $\left[{ }^{3} \mathrm{H}\right] \mathrm{TdR}$ incorporation from triplicate cultures in a representative experiment. Background counts per minute were $<1,000$, and were not subtracted.

the former but not the latter. Increasing the number of sera studied in this fashion to 28 did not strengthen this association statistically. However comparisons of inhibition of the tetanus toxoid and PHA responses by regression analysis revealed a significant relationship (Pearson correlation coefficient $=0.56$,

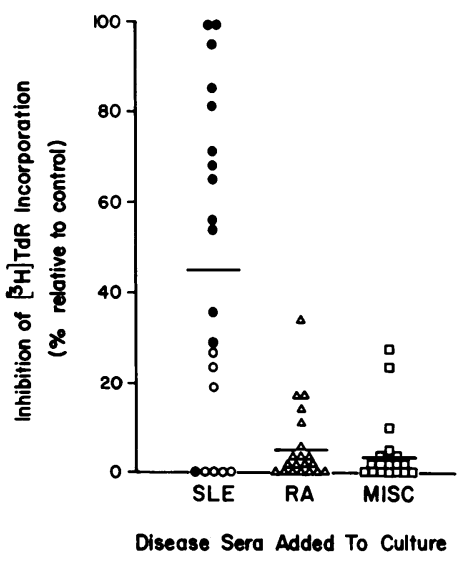

Figure 2. Inhibition of tetanus toxoid-induced $\mathrm{T}$ cell proliferation by SLE and other rheumatic disease sera. Percentage inhibition of peak $\left[{ }^{3} \mathrm{H}\right] \mathrm{TdR}$ incorporation measured on day 5 relative to parallel cultures containing a standard normal AB serum was most marked for active SLE sera (๑). Sera from patients with inactive SLE (o), rheumatoid arthritis $(\Delta)$, and miscellaneous (MISC) rheumatic diseases $(\square)$ generally lacked inhibitory activity. Inhibition by 10 normal sera was negligible $($ mean $\pm \mathrm{SD}=13 \pm 10 \%)$. All sera were present continuously from the outset of culture. 
$P=0.01)$. This suggested that a common inhibitory effect did indeed exist for SLE serum in both the antigen- and mitogeninduced $T$ cell responses. Modest inhibition of the PHA response was seen with RA and certain miscellaneous rheumatic disease sera, a finding that contrasted with the uniform failure of such sera to inhibit tetanus toxoid-stimulated cultures. These data suggest that SLE serum exerts a quantitatively more potent effect on antigen-induced $T$ cell responses and argue against a major role for nonspecific influences on cellular proliferation in general.

Relationship to SLE disease activity and therapy. Thirteen of the 20 patients with SLE were classified on clinical grounds as having active disease at the time of study. This group had lower $\mathrm{CH}_{50}$ levels (mean $\pm \mathrm{SD}=19 \pm 15 \mathrm{U} / \mathrm{ml}$; normal, 25-40 $\mathrm{U} / \mathrm{ml})$ and were relatively more lymphopenic $(694 \pm 360 \mathrm{lym}-$ phocytes $\left./ \mathrm{mm}^{3}\right)$ than the seven inactive patients $\left(\mathrm{CH}_{50}=29 \pm 9\right.$ $\mathrm{U} / \mathrm{ml}$; absolute lymphocytes, $1,108 \pm 241 / \mathrm{mm}^{3}$ ). Inhibition of the tetanus toxoid response was higher for active SLE sera $($ mean \pm SD $=64 \pm 30 \%)$ than for inactive SLE sera $(10 \pm 13 \%)$. Such a marked difference in the degree of inhibition was not observed in PHA-stimulated cultures (inhibition by active SLE sera, $34 \pm 29 \%$; inhibition by inactive SLE sera, $16 \pm 19 \%$ ).

13 of the patients were being treated with prednisone. Although the average daily dose in $8 / 11$ patients whose sera inhibited the tetanus toxoid responses was higher $20 \pm 17$ $\mathrm{mg} / \mathrm{d})$ than in the $5 / 9$ patient sera that did not $(11 \pm 10 \mathrm{mg} / \mathrm{d})$, there was little difference in inhibitory activity for sera from corticosteroid-treated and untreated patients (mean inhibition $=52 \pm 30$ and $42 \pm 40 \%$, respectively). Inhibition of the PHA response also was similar in the treated $(32 \pm 29 \%)$ and untreated $(20 \pm 22 \%)$ patients.

Inhibition of the tetanus toxoid and PHA responses by SLE serum Ig. The activity in SLE serum that inhibited the tetanus toxoid response was recovered in both IgM and IgG fractions obtained by sucrose density gradient ultracentrifugation using pH 3.5 buffers. In certain sera, both IgM and IgG inhibited the tetanus toxoid response; on a molar basis, however, IgG was less inhibitory than IgM. For example, with two such sera, the final concentrations of IgM giving 50\% inhibition were 11 and $40 \mu \mathrm{g} / \mathrm{ml}$, whereas 270 and $260 \mu / \mathrm{ml}$ of IgG were required. In other patients, very low concentrations of IgM were inhibitory, but IgG was inactive (Table I). To demonstrate further the Ig class, IgM was purified from a pool of six SLE sera by affinity chromatography. At a final concentration in culture of $20 \mu \mathrm{g} / \mathrm{ml}$, this highly purified IgM gave 50\% inhibition of the response. Inhibition was not observed with IgG or IgM fractions from normal sera, or with Ig from patients with inactive SLE who lacked inhibitory activity in whole serum.

The recovery of inhibitory activity in acid $\mathrm{pH}$ gradient fractions from SLE sera was of special interest because this suggested that antibodies, rather than immune complexes, were involved. The failure of heat-aggregated normal IgG (final concentration, $200 \mu \mathrm{g} / \mathrm{ml}$ ) to inhibit provided additional evidence in this regard. To exclude further an inhibitory effect of immune complexes in SLE serum or Ig fractions, six sera
Table I. Inhibition of Tetanus Toxoid-induced T Cell Proliferation by SLE Serum IgM: Relationship to Anti-T Blast Antibody Activity

\begin{tabular}{|c|c|c|c|c|c|c|c|c|}
\hline & \multirow{2}{*}{\multicolumn{2}{|c|}{$\begin{array}{l}\text { Ig conc } \\
(\mu g / m l)^{*}\end{array}$}} & \multirow{2}{*}{\multicolumn{2}{|c|}{$\begin{array}{l}\text { Inhibition of } \\
{\left[{ }^{3} \mathrm{H}\right] \mathrm{TdR}} \\
\text { incorp (\%) }\end{array}$}} & \multicolumn{4}{|c|}{ Anti-T blast antibody } \\
\hline & & & & & \multicolumn{2}{|c|}{ C-cytotox (\%)\& } & \multicolumn{2}{|c|}{$\begin{array}{l}\text { IF staining } \\
(\text { () })^{\prime \prime}\end{array}$} \\
\hline & IgM & IgG & IgM & IgG & IgM & IgG & IgM & IgG \\
\hline Su(SLE) & 9 & 162 & 64 & 11 & 20 & $<10$ & 58 & $<1$ \\
\hline He(SLE) & 8 & 190 & 40 & 5 & 30 & $<10$ & 35 & $<1$ \\
\hline Mc(SLE) & 5 & 163 & 39 & 19 & 20 & $<10$ & 18 & $<1$ \\
\hline SLE pool & 20 & $<2$ & 50 & & 70 & & 80 & $<1$ \\
\hline Normal & 33 & 410 & 0 & 8 & $<10$ & $<10$ & $<1$ & $<1$ \\
\hline
\end{tabular}

* Final concentration (conc) per culture of IgM and IgG fractions. IgM was isolated from SLE patients $\mathrm{Su}, \mathrm{He}$, and $\mathrm{Mc}$, and from normal serum as the $19 \mathrm{~S}$ fraction by sucrose density gradient ultracentrifugation using $\mathrm{pH} 3.5$ buffers. IgM from a pool of six SLE sera was purified by affinity chromatography. IgG was prepared free of contaminating IgM by ammonium precipitation followed by DEAE cellulose chromatography.

$¥$ Calculated as percentage inhibition of $\left[{ }^{3} \mathrm{H}\right] \mathrm{TdR}$ incorporation (incorp) by IgM or IgG serum fractions on day 5 relative to control cultures containing $10 \%$ standard normal $\mathrm{AB}$ serum.

$\S$ Determined with IgM or IgG serum fractions in parallel two-stage microcytotoxicity assays performed at $25^{\circ} \mathrm{C}$. IgG concentrations in cytotoxicity (cytotox) and immunofluorescence assays were 20-fold higher than those shown; values represent percentage dead cells. " Determined with whole serum by indirect immunofluorescence (IF) using FITC-F(ab') anti-IgM or FITC-F(ab') anti-IgG reagents. Values represent percentage stained cells.

and the affinity purified IgM were ultracentrifuged at 105,000 $g$ for $2 \mathrm{~h}$ at $4^{\circ} \mathrm{C}$. After ultracentrifugation, which removes Clq binding activity (15), the top, middle, and bottom thirds of each sample were compared in tetanus toxoid inhibition assays. As shown in Table II, this treatment had little effect on inhibitory activity. In other experiments, $19 \mathrm{~S}$ IgM fractions that inhibited the response (Table I) were examined for immune complex-like activity in a fluid-phase Clq binding assay (kindly performed by Dr. Greg Bisecker (Hahnemann University, Philadelphia, PA). Immune complexes were not detected (sensitivity, $5 \mu \mathrm{g} / \mathrm{ml})$.

Increased serum Ig per se, or anti-tetanus toxoid antibody in the SLE sera did not contribute to inhibition of the tetanus toxoid response. Mean serum Ig levels in the SLE patients (IgG, $14.7 \pm 11.8 \mathrm{mg} / \mathrm{ml}$; IgM, $1.8 \pm 3.3 \mathrm{mg} / \mathrm{ml}$ ), while higher than in the 10 normal subjects $(\mathrm{IgG}, 11.9 \pm 2.6 \mathrm{mg} / \mathrm{ml}$; IgM, $1.3 \pm 0.4 \mathrm{mg} / \mathrm{ml}$ ), were similar to the levels in RA sera (IgG, $18.3 \pm 6.5 \mathrm{mg} / \mathrm{ml}$; IgM, $1.8 \pm 1.0 \mathrm{mg} / \mathrm{ml}$ ), which were not inhibitory. Furthermore, there was no relationship between Ig concentration and inhibitory activity in individual SLE sera. 
Table II. Effect of Ultracentrifugation on Inhibitory Activity in SLE Serum

\begin{tabular}{llll}
\hline & \multicolumn{2}{l}{$\begin{array}{l}\left.\text { Inhibition of }{ }^{3} \mathrm{H}\right] \mathrm{TdR} \text { incorporation after ultracentrifugation } \\
\text { (\% relative to control) }\end{array}$} \\
\cline { 2 - 4 } Patient & Upper $1 / 3$ & Middle 1/3 & Bottom 1/3 \\
\hline $\mathrm{Ta}$ & 90 & 92 & 99 \\
$\mathrm{Ch}$ & 97 & 99 & 99 \\
$\mathrm{Heg}$ & 98 & 98 & 99 \\
$\mathrm{Mi}$ & 99 & 98 & 96 \\
$\mathrm{Mc}$ & 77 & 83 & 86 \\
$\mathrm{Gi}$ & 53 & 42 & 68 \\
SLE IgM & 48 & 50 & 68 \\
\hline
\end{tabular}

Samples were ultracentrifuged for $2 \mathrm{~h}$ at $4^{\circ} \mathrm{C}$. The upper, middle, and bottom thirds were then compared in a tetanus toxoid inhibition assay. SLE IgM was purified by affinity chromatography from a pool of six serum using anti-IgM Sepharose 4B.

Anti-tetanus toxoid antibody titers as determined by hemagglutination were actually lower in the SLE sera than in the RA or normal sera (data not shown). Finally, human tetanus immune globulin that contained anti-tetanus toxoid antibody in a titer of $>1: 1,000$ per milligram IgG did not inhibit the response when added to cultures in a final concentration of $420 \mu \mathrm{g} / \mathrm{ml}$.

Association of inhibition with antilymphocyte antibody. Conventional cold-reactive antilymphocyte antibodies were demonstrable in $8 / 11(73 \%)$ of SLE sera that inhibited tetanus toxoid $\mathrm{T}$ cell proliferation, as determined in two-stage microcytotoxicity assays performed at $15^{\circ} \mathrm{C}$ using unstimulated PBMCs as targets. Conversely, $6 / 9$ sera $(67 \%)$ that did not inhibit the response lacked such antibodies, suggesting that at least one inhibitory component in SLE serum might be an antilymphocyte antibody. Also supporting this possibility was the relative absence of lymphocytotoxic antibodies in the nonSLE sera which, in general, failed to inhibit the tetanus toxoid response (normal sera, $0 / 10$ positive; RA sera, $5 / 20$ positive; and miscellaneous rheumatic disease sera, $3 / 20$ positive).

To define the mononuclear cell specificity of antibodies in SLE serum that might be involved in inhibition of tetanus toxoid-stimulated $\mathrm{T}$ cell proliferation, correlative studies were performed using well-characterized PBMC subpopulations and activated $T$ cells as targets. In these experiments, the thermal amplitude of the cytotoxic antibodies was assessed by cold $\left(15^{\circ} \mathrm{C}\right)$ and warm $\left(25^{\circ} \mathrm{C}\right)$ assay temperatures. As shown in Figs. 3 and 4, a particularly strong relationship was evident for relatively warm-reactive antibodies directed toward $T$ cell blasts ( $P=0.006$ by two-tail Fisher's exact test; Pearson correlation coefficient $=0.67, P=0.0012$ ). In such $25^{\circ} \mathrm{C}$ assays, the great majority of SLE sera $(17 / 20)$ were noncytotoxic for unstimulated $T$ cells. However, when cytotoxicity for unstimulated $\mathrm{T}$ cells was examined at $15^{\circ} \mathrm{C}$, a significant, albeit

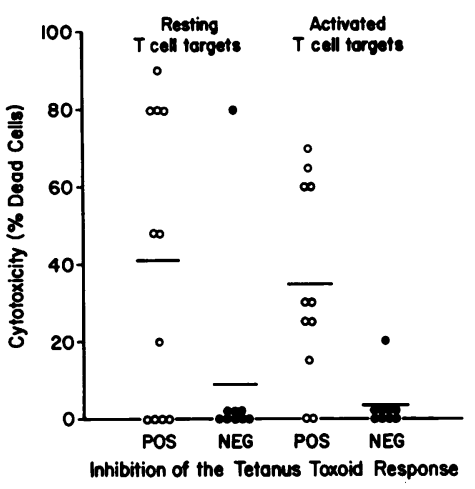

Figure 3. Association of anti-T cell antibody with capacity to inhibit the tetanus toxoid $T$ cell proliferative response. SLE sera that significantly inhibited the tetanus toxoid response ( 0 ) exhibited increased antibody activity against both resting $T$ cells and $T$ cell blasts as determined in C-dependent cytotoxicity assays. Sera that did not inhibit the tetanus toxoid re-

sponse (๑) generally lacked such antibodies. Inhibitory activity was more strongly associated with warm-reactive anti-T blast antibody $(P$ $=0.006)$ than with cold-reactive antibody to resting $\mathrm{T}$ cells $(P$ $=0.03$ ). Significant inhibition was defined as $>2$ SD above the mean value for 10 normal sera. POS, positive; NEG, negative.

weaker, association between inhibition of the tetanus toxoid response and cold-reactive antibody activity was apparent (Fisher's exact test, $P=0.03$ ). Low levels ( $<15 \%$ killing) of warm-reactive antibodies were detected in only 2/20 RA sera and 3/20 miscellaneous rheumatic disease sera.

The antibodies to activated $T$ cells in sera that inhibited the tetanus toxoid response were predominantly of the IgM class. IgM fractions obtained under immune complex-dissociating conditions from certain strongly inhibitory sera contained anti-T blast cytotoxic activity, whereas highly purified IgG from the same sera did not (Table I). Conversely, IgM fractions from three patients that lacked the capacity to inhibit the response also lacked anti-T blast antibody. Indirect immunofluorescent staining of $T$ cell blasts in sera inhibiting the tetanus toxoid response was higher for IgM (mean \pm SD positive cells $=43 \pm 30 \%$ ) than for IgG (percentage positive cells $=4 \pm 9 \%$ ), although staining in the range of $\sim 25 \%$ was seen with several sera. Affinity purified IgM from a pool of six SLE sera lysed $70 \%$ of activated $\mathrm{T}$ cells in the presence of complement when assayed at a concentration of $400 \mu \mathrm{g} / \mathrm{ml}$, and inhibited the tetanus toxoid response $50 \%$ when added to

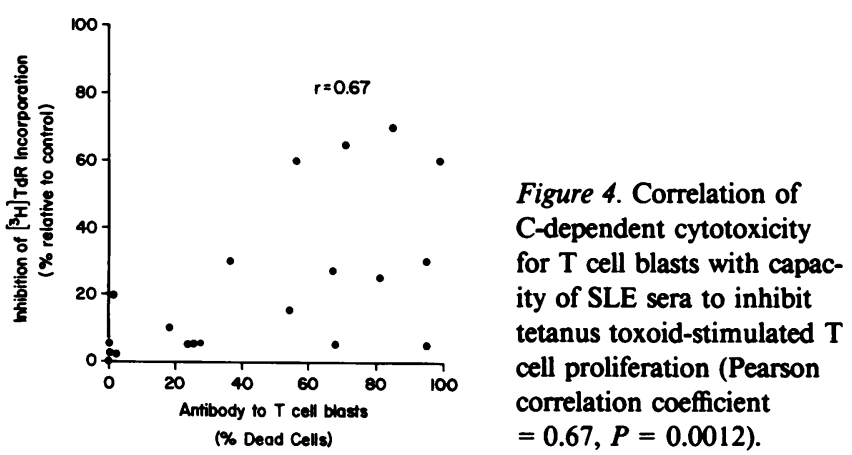


cultures at a final concentration of $20 \mu \mathrm{g} / \mathrm{ml}$. Finally, ultracentrifugation of serum or serum IgM fractions reduced neither IgM staining of $T$ cell blasts (data not shown) nor inhibition of tetanus toxoid blastogenesis.

Cytotoxic antibodies to non-T cells obtained as nylon wool-adherent cells (>85\% Ia,$+ 40-70 \%$ SIgM+, 15-40\% esterase + , and 5-15\% OKT3+) were not associated with inhibition of the tetanus toxoid response $(P=0.17)$. Antibodies to plastic adherent cells, consisting of $80-90 \%$ esterase + monocytes, were demonstrable in only $2 / 20$ SLE sera. In other experiments, SLE sera were examined for their capacity to develop reverse hemolytic plaques by the use of tetanus toxoid and PHA blast cells as targets (37). Only 6/20 sera developed T-plaque-forming cells, and this was not related to inhibition of the tetanus toxoid response.

Additional evidence to suggest a role for anti-T cell blast antibodies in inhibition of the tetanus toxoid response was obtained in a series of absorption experiments. Four SLE sera with anti-T blast antibodies (cytotoxicity, 50, 55, 80, and 90\%) were exhaustively absorbed with nylon wool-enriched resting peripheral T cells, or with tetanus toxoid- or PHA-stimulated $T$ cell blasts, and examined for residual inhibition of the tetanus toxoid response. $T$ cell blasts of either type completely removed the inhibitory activity (Fig. 5). Absorption with unstimulated $\mathbf{T}$ cells was uniformly ineffective in this regard. $T$ cell blast absorptions eliminated ( $<10 \%$ residual cytotoxicity)

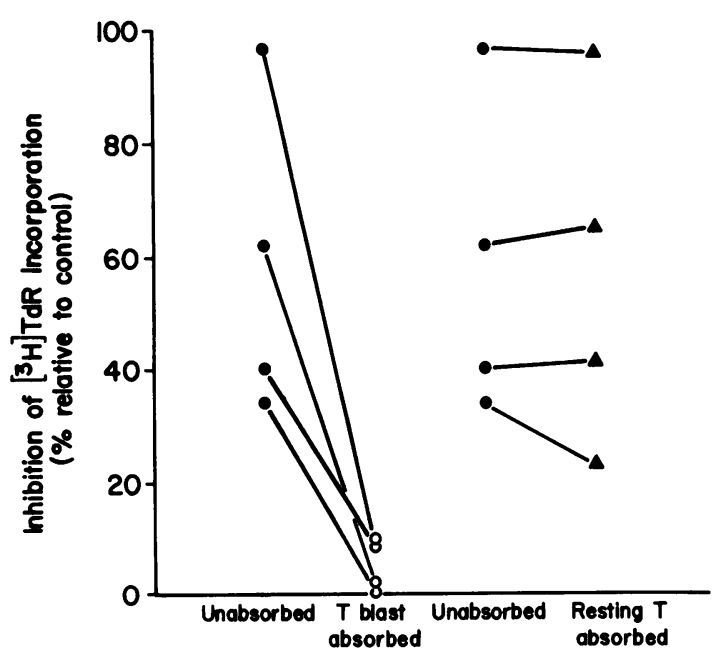

Figure 5. Reduction in the capacity to inhibit the tetanus toxoid response after absorption of SLE sera with $T$ cell blasts. Sera from four patients with SLE were exhaustively absorbed with either resting $T$ cells $(\Lambda)$ or tetanus toxoid-stimulated T cell blasts harvested on day 5 (0). Unabsorbed (๑) and absorbed sera were then compared for inhibitory activity in tetanus toxoid proliferation assays using PBMCs from the same donor used in the absorption experiments. $T$ blast absorptions eliminated cytotoxic antibodies to both resting and activated $T$ cells. Resting $T$ cell absorptions removed only antibodies cytotoxic for resting $T$ cells. both warm-reactive antibodies cytotoxic for $\mathrm{T}$ cell blasts and cold-reactive antibodies to unstimulated $T$ cells. In the converse experiment, absorption with unstimulated $\mathrm{T}$ cells decreased warm-reactive cytotoxicity for $\mathrm{T}$ cell blasts $<10 \%$ relative to unabsorbed serum in three patients, and $44 \%$ (from 80 to $45 \%$ killing) in the fourth. In other experiments, a T cell line (HSB) partially absorbed inhibitory activity from three of four sera, but to a lesser degree than did the peripheral blood $\mathrm{T}$ cell blasts. An Ia + B cell line (2080) removed $>95 \%$ of inhibitory activity from one serum but not from three others $(<5,10$, and $35 \%$ reduction relative to unabsorbed serum). These data suggested that inhibition of the tetanus toxoid response involved antibody to surface determinants expressed either de novo on activated $T$ cells or in greater density relative to unstimulated cells.

To clarify further the question of specificity for activation neoantigen(s) vs. resting $T$ cell antigen(s), which were relatively increased in density on activated cells, additional absorptions (six instead of two) with unstimulated T cells were performed (Table III). This procedure reduced the starting IgM concentration by $\sim 10 \%$, e.g., from 2.0 to $1.8 \mathrm{mg} / \mathrm{ml}$. As shown, neither warm-reactive cytotoxicity for $T$ cell blasts nor the capacity to inhibit the tetanus toxoid response was eliminated, although a partial reduction in $\mathrm{T}$ blast cytotoxicity was observed with one serum.

To demonstrate directly that antibodies to activated $T$ cells inhibited the tetanus toxoid response, eluates were obtained by $37^{\circ} \mathrm{C}$ incubation of $\mathrm{T}$ blasts used for absorption. Each of three eluates inhibited the response: Mi eluate, 71\%; Ta eluate, $41 \%$; and $\mathrm{He}$ eluate, $35 \%$. Inhibitory activity in the eluates was associated with recovery of warm-reactive cytotoxic antibody against $\mathrm{T}$ cell blasts: Mi eluate, $80 \%$ killing; and $\mathrm{Ta}$ eluate and He eluates, $30 \%$ killing. Inhibition was not observed with control eluates.

Kinetics and mechanism of inhibition. As shown in Table IV, the kinetics of inhibition of the tetanus toxoid response were similar to those observed with L243, a monoclonal antiDR framework antibody (40); i.e., considerably greater inhibition occurred when serum was added at the initiation of culture than at later times. Antibody to Tac, the IL-2 receptor (41), was inhibitory when added as late as day 3 . This suggested that interference with early events in the tetanus toxoid response was operant. To examine this issue, peripheral blood plastic adherent cells were incubated for $18 \mathrm{~h}$ at $37^{\circ} \mathrm{C}$ with tetanus toxoid in the presence of either SLE serum or normal AB serum. After thorough washing, the antigen-pulsed adherent cells were recombined with fresh purified $\mathrm{T}$ cells. Incorporated $\left[{ }^{3} \mathrm{H}\right] \mathrm{TdR}$ on day 5 was compared with that seen with unfractionated PBMCs exposed to antigen and cultured with SLE serum throughout, or in reconstituted cultures to which SLE serum was not added until the antigen-pulsed cells were recombined with $T$ cells. Four SLE sera were studied in this fashion. Serum present only during the $18 \mathrm{~h}$ that adherent cells were pulsed with tetanus toxoid did not inhibit $T$ cell proliferation in reconstituted cultures (mean inhibition \pm SD 
Table III. Failure of Repeated Absorptions* of SLE Serum with Unstimulated T Cells or Erythrocytes to Remove Tetanus Toxoid Response Inhibitory Activity or Cytotoxic Antibody to T Cell Blasts

\begin{tabular}{|c|c|c|c|c|c|c|c|c|}
\hline \multirow[b]{2}{*}{$\begin{array}{l}\text { SLE } \\
\text { serum }\end{array}$} & \multicolumn{4}{|c|}{ Inhibition of $\left[{ }^{3} \mathrm{H}\right] \mathrm{TdR}$ incorp (\%) $\neq$} & \multicolumn{4}{|c|}{ T cell blast cytotoxicity (\% dead cells) $\$$} \\
\hline & Unabs & RBC abs & $\begin{array}{l}\text { Resting T } \\
\text { cell abs }\end{array}$ & $\begin{array}{l}\mathrm{T} \text { cell } \\
\text { blast abs }\end{array}$ & Unabs & RBC abs & $\begin{array}{l}\text { Resting T } \\
\text { cell abs }\end{array}$ & $\begin{array}{l}\mathrm{T} \text { cell } \\
\text { blast abs }\end{array}$ \\
\hline $\mathrm{Hg}$ & 42 & 50 & 39 & 11 & 70 & 70 & 60 & 40 \\
\hline Su & 52 & 52 & 55 & 9 & 60 & 60 & 20 & $<10$ \\
\hline Sm & 82 & 82 & 86 & 4 & $>95$ & $>95$ & $>95$ & $<10$ \\
\hline
\end{tabular}

Unabs, unabsorbed; abs, absorbed. ${ }^{*} 200 \mu$ l of SLE serum was absorbed six times, instead of the usual two times, with $1 \times 10^{7}$ unstimulated T cells or an equivalent volume of packed erythrocytes (RBC), per absorption, and then examined for capacity to inhibit the 5-d tetanus toxoid response and for residual cytotoxicity for $\mathrm{T}$ cell blasts. Data obtained after absorptions with $\mathrm{T}$ cell blasts (two times with $1 \times 10^{7}$ cells per absorption) are shown for comparison. $¥ \%$ Inhibition of $\left[{ }^{3} \mathrm{H}\right] \mathrm{TdR}$ incorporation was calculated from triplicate values based upon a mean counts per minute of 21,736 (stimulation index $=23.6$ ) in control cultures containing $10 \%$ normal $\mathrm{AB}$ serum. $\S$ Determined in parallel twostage C-dependent cytotoxicity assays performed at $25^{\circ} \mathrm{C}$. Residual cytotoxicity at $15^{\circ} \mathrm{C}$ for unstimulated $\mathrm{T}$ cells after resting $\mathrm{T}$ cell absorptions was $<10 \%$ in each case.

$=21 \pm 20 \%)$. Exposure to SLE serum after tetanus toxoidpulsed adherent cells and $T$ cells were recombined resulted in inhibition $(46 \pm 50 \%)$ nearly as marked as that seen when PBMCs were cultured with antigen and SLE serum beginning at day $0(64 \pm 34 \%)$. These data suggested that SLE serum was acting upon relatively early activation events at the $T$ cell level rather than upon antigen processing by accessory cells.

To elucidate further the mechanism of inhibition, the proportion of cells expressing IL-2 receptors (Tac) and the relative surface membrane density of Tac on $T$ cells during the tetanus toxoid response was determined by indirect immunofluorescence and flow microfluorometry procedures (Fig.

Table IV. Kinetics of Inhibition of the Tetanus Toxoid and PHA Proliferative Responses by SLE Serum and Various Monoclonal Antibodies to Cell Surface Determinants

\begin{tabular}{|c|c|c|c|c|c|c|}
\hline \multirow{3}{*}{$\begin{array}{l}\text { Day } \\
\text { added } \\
\text { to culture }\end{array}$} & \multicolumn{6}{|c|}{ Inhibition of $\left[{ }^{3} \mathrm{H}\right] \mathrm{TdR}$ incorporation (\% of control $)^{*}$} \\
\hline & \multicolumn{2}{|c|}{ SLE serum } & \multicolumn{2}{|l|}{ Anti-la } & \multicolumn{2}{|c|}{ Anti-Tac } \\
\hline & Tet tox & PHA & Tet tox & PHA & Tet tox & PHA \\
\hline 0 & $74 \pm 13$ & $40 \pm 4$ & 78 & 12 & 60 & $<10$ \\
\hline 1 & $27 \pm 12$ & $29 \pm 12$ & 56 & $<10$ & 61 & $<10$ \\
\hline 2 & $25 \pm 12$ & $33 \pm 15$ & $<10$ & $<10$ & 55 & $<10$ \\
\hline 3 & $31 \pm 1$ & $28 \pm 12$ & 18 & $<10$ & 52 & $<10$ \\
\hline 4 & $10 \pm 7$ & & 20 & & $<10$ & \\
\hline 5 & $<10$ & & 15 & & $<10$ & \\
\hline
\end{tabular}

* Values for SLE serum represent the mean \pm SD inhibition for sera from four different patients selected for inhibitory activity in both the tetanus toxoid (tet tox) and PHA responses. The highest dilution of the monoclonal anti-Ia (L243) and anti-Tac antibodies that gave maximum inhibition when added on day 0 was used. Control cultures contained $10 \%$ normal $\mathrm{AB}$ serum.
6). In control cultures, the percentage of Tac + cells increased progressively in association with a shift toward staining of higher fluorescence intensity. In SLE serum-inhibited cultures, the expression of Tac was markedly attenuated. Similar results were obtained when Tac+ cells were enumerated by monoclonal antibody rosetting (data not shown). In related experiments, the addition of exogenous IL- 2 on day 0 or day 1 dramatically enhanced maximum day $5\left[{ }^{3} \mathrm{H}\right] \mathrm{TdR}$ incorporation in control cultures but only partially restored the response in SLE serumcontaining cultures (Fig. 7). Collectively, these data provide further evidence that the early phase inhibitory effect of SLE serum on peak proliferation involved interference with the initial expression of IL-2 receptors, and, as a consequence, with responsiveness to IL-2.

Specificity of antilymphocyte antibodies. Because others have reported antibodies to Ia in SLE sera (30) with potent suppressive effects on $\mathrm{T}$ cell proliferative responses involving recognition of Ia determinants (42), autoantibodies to Ia appeared to be particularly attractive candidates to explain the early phase inhibition of the tetanus toxoid response by SLE serum. Several approaches were used in efforts to demonstrate such antibodies. First, pre-incubation of CLL cells $(\sim 65 \%$ Ia + ) or $\mathrm{T}$ cell blasts $(\sim 20 \% \mathrm{Ia}+)$ at $4^{\circ} \mathrm{C}$ with the 20 SLE sera before addition of an appropriate dilution of monoclonal antiDR framework antibody L243 did not inhibit rosette formation between the anti-Ia-coated target cells and goat anti-mouse IgG-coated ox erythrocytes. Mean inhibition in the presence of SLE serum was only $3 \pm 5 \%$, well within the range observed with a panel of 10 normal sera, $2 \pm 5 \%$. Similar data were obtained with Leu-10, a monoclonal antibody with DS/DC framework specificity. In contrast, both rabbit and chicken anti-Ia antibodies inhibited rosette formation by $>95 \%$. As it is possible that the putative anti-Ia antibody in SLE serum must be directed at the identical epitope with which L243 reacts in order to inhibit rosette formation, attempts were 
Resting $T$ cells

(2\% Tac pos)

(13\% Tac pos)

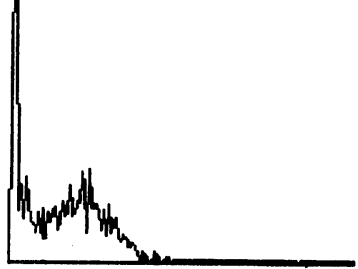

Day 5-AB Serum

(29\% Tac pos)
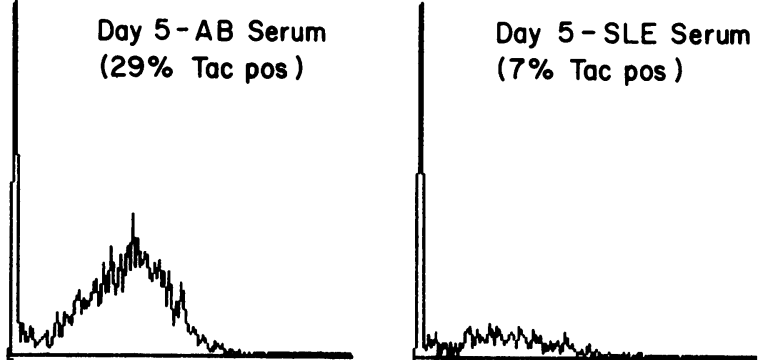

Figure 6. SLE serum inhibits the expression of IL-2 receptors. The proportion of $T$ cells expressing IL-2 receptors was determined in tetanus toxoid-stimulated PBMC cultures containing normal AB serum or SLE serum by indirect immunofluorescence and flow microfluometry using anti-Tac. SLE serum markedly reduced the percentage Tac+ cells throughout the $5 \mathrm{~d}$ of culture. Overall surface membrane density of IL-2 receptors, as assessed by relative fluorescence intensity of Tac staining, also was reduced by SLE serum. Number of cells is along the ordinate; relative fluorescence intensity of Tac staining is along the abscissa.

made to modulate Ia antigen from the target cells by a 2-h $37^{\circ} \mathrm{C}$ pre-incubation with SLE serum. CLL cells treated in this way showed no decrease in L243 rosettes: $41 \pm 9$ vs. $39 \pm 15 \%$ in normal human serum control assays. In other experiments, the presence of anti-Ia antibodies was sought in an assay based on inhibition of $\mathrm{C}$-mediated cytotoxicity using chicken anti-Ia antibody, which does not fix C. Pre-incubation of nylon wool-purified non-T cells (85\% Ia+) with chicken anti-Ia completely prevented killing by $\mathrm{L} 243$ but had no effect on cytotoxicity by the SLE sera.

In studies to be reported in detail separately (42a), antibodies to a number of other cell surface antigens were sought using

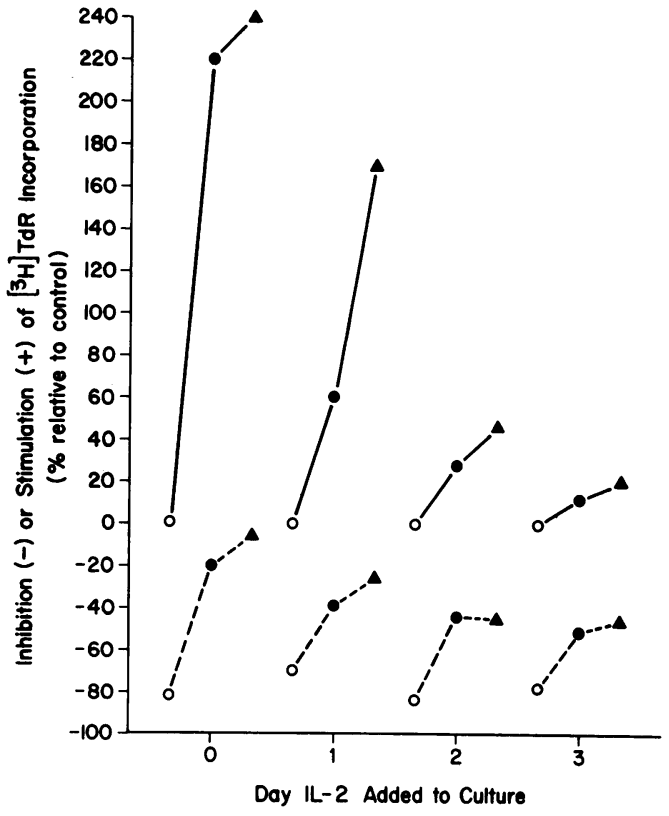

Figure 7. Decreased responsiveness of SLE serum inhibited tetanus toxoid cultures to exogenous IL-2. Purified human IL-2, $12.8(\bullet)$ or 25.6 ( $)$ half-maximal $\left[{ }^{3} \mathrm{H}\right] \mathrm{TdR}$ units per culture, was added at time 0 or on days 1-3 to cultures containing either standard normal $A B$ serum (-) or SLE serum (- - ) present continuously from time 0 . Incorporated $\left[{ }^{3} \mathrm{H}\right] \mathrm{TdR}$ was determined on day 5 . Data represent percentage $\left[{ }^{3} \mathrm{H}\right] \mathrm{TdR}$ uptake relative to that observed in $\mathrm{AB}$ serum control cultures (O). IL-2 partially restored the T cell proliferative response of $\sim 80 \%$ inhibited SLE serum-containing cultures. Marked enhancement above control was seen in $A B$ serum-containing cultures, especially when IL-2 was added at time 0 or day 1 .

these approaches. Surface determinants studied on resting or PHA-activated T cell targets included: T3, T11, Leu-1, Leu-8 (pan-T); T4, T8 (T subset); $\beta_{2 m}$; and Tac, 5E9, and AA1 (other activation antigens). Significant rosette inhibition, either directly at $4^{\circ} \mathrm{C}$ or after modulation of IgM antilymphocyte antibody-reactive target cell antigen at $37^{\circ} \mathrm{C}$, was seen only for $\beta_{2 m}(13 / 20$ sera positive; inhibition, $17-58 \%)$. Next, relative fluorescence intensity of lymphocyte staining by FITC-conjugated monoclonal antibodies was assessed by flow microfluorometry after modulation of SLE antibody-reactive antigen. Modulation typically reduced both the fluorescence intensity of SLE antilymphocyte antibody IgM staining and the percentage of $\mathrm{T}$ cells scored as IgM $+(60-95 \%$ IgM $+\rightarrow 15-35 \%$ IgM+). Except for $\beta_{2 m}$, however, the relative fluorescence intensity for the known surface antigens was not altered (data not shown).

\section{Discussion}

Several lines of evidence indicate that relatively warm-reactive antibodies to activated T cells in SLE exert potent inhibitory 
effects upon antigen-induced $\mathrm{T}$ cell proliferation. First, inhibition of the $T$ cell response to tetanus toxoid was highly correlated with the presence of such antibodies in serum of patients with active disease. Inhibition was not observed with sera from patients with inactive SLE or with non-SLE rheumatic diseases, or with sera from normal subjects that lacked anti-T blast antibodies. Second, both inhibitory activity and cytotoxic antibody to $\mathrm{T}$ cell blasts were localized to serum Ig, including fractions isolated by use of immune complex-dissociating conditions. Both IgM and IgG antibodies were identified, although the former was most active. Third, $\mathrm{T}$ cell blasts absorbed completely the capacity to inhibit the tetanus toxoid response in parallel with removal of anti- $T$ cell antibody; absorption with resting $T$ cells eliminated cold-reactive cytotoxicity for unstimulated $\mathrm{T}$ cells but did not decrease inhibitory activity or anti-T cell blast antibody. Finally, warm-reactive cytotoxic antibody and inhibitory activity were recovered in $37^{\circ} \mathrm{C}$ eluates from activated $\mathrm{T}$ cells after absorption at $4^{\circ} \mathrm{C}$.

Other factors in SLE serum that potentially could inhibit the tetanus toxoid response include immune complexes, corticosteroids (43), anti-tetanus toxoid antibody, and anti-tetanus toxoid auto-antiidiotypic antibodies (44). Although some contribution to inhibitory effects of whole serum by immune complexes or corticosteroids is difficult to exclude entirely, such nonantibody factors did not appear to play a significant role. Thus, inhibitory activity could be recovered in Ig fractions that were isolated under immune complex-dissociating conditions and that did not contain demonstrable immune complexes. Heat-aggregated IgG did not inhibit. In addition, inhibitory activity was not removed by ultracentrifugation. There was no relationship between therapy and inhibition of the response, and several of the SLE sera that were most inhibitory were from patients with active disease who were receiving no therapy. Similarly, it is unlikely that inhibition was due to an anti-tetanus toxoid antibody or auto-antiidiotypic antibodies. Tetanus toxoid antibody titers in the SLE patients were not higher than those in normal subjects or patients with non-SLE disorders that did not inhibit. Antibody inhibiting the response could be absorbed completely with PHA-induced T cell blasts, which would not be expected to express the tetanus toxoid idiotype to any significant degree. Tetanus immune globulin had no effect on the response.

Antibodies to $T$ cell blasts have been described previously in RA (45) and SLE (31). In SLE, IgG antibodies react with soluble products of activated $T$ cells. No association of this interesting type of antibody with inhibition of the $T$ cell tetanus toxoid response was apparent, however. In RA, IgM antibodies exhibit increased cytotoxicity for $T$ blasts but can be absorbed completely with unstimulated cells. The absorption data in SLE suggest that anti-T blast antibodies are directed to a neoantigen(s) not expressed on resting $\mathrm{T}$ cells, although it remains possible that the preferential activity with $T$ blasts reflects increased surface membrane expression of a determinant also present on unstimulated $\mathrm{T}$ cells, but at very low density.
If such were the case, cold-reactive IgM antibodies to resting $T$ cells might also contribute to inhibition of the tetanus toxoid response, as has been suggested previously (46). Further studies will be required to clarify the relationships among these interesting anti- $T$ cell antibody systems.

The kinetics of inhibition of the $T$ cell response to tetanus toxoid by SLE serum closely paralleled those of anti-Ia. This suggested that anti-T cell antibodies in SLE interfere with the induction of $T$ cell activation, or with early events in the activation phase that take place during the first 24-48 h of culture $(47,48)$. Proliferation occurring later involves committed cells no longer requiring IL-2 or antigen $(48,49,50)$ and was not inhibited by SLE serum. An effect at the level of the antigen-presenting cell, which must internally process antigen and recycle it to the cell surface for association with Ia molecules as the critical first signal (50), is unlikely. Thus, $\left[{ }^{3} \mathrm{H}\right] \mathrm{TdR}$ incorporation by $\mathrm{T}$ cells stimulated by macrophages pulsed with tetanus toxoid in the presence of SLE serum was not reduced, a finding consistent with the absence of demonstrable antimonocyte antibodies in most sera. Despite considerable effort, antibodies to Ia of the type described previously in sera from patients with active $\operatorname{SLE}(30,42)$ could not be detected. SLE sera did not inhibit monoclonal anti-DR and anti-DS/DC framework rosette formation, whereas rabbit and chicken anti-Ia reagents were quite effective in this regard. Absorption with an Ia + B cell line failed to decrease inhibitory activity on the tetanus toxoid response in three of four SLE sera. Nevertheless, the fact that antigen may be presented in the context of class II molecules other than DR (51), and the limited data obtained thus far against the presence of putative Ia specificities, certainly leave open the possibility of Ia blockade. The failure of many SLE sera to inhibit blastogenesis induced by suboptimal concentrations of PHA argues against any interference with delivery of the second signal for $T$ cell activation, i.e., interleukin-1 (IL-1) production by macrophages and IL-1/IL-1 receptor interaction.

The action of antibody on $T$ cells responding to inductive stimuli is more consistent with the present data. Greater inhibition of the tetanus toxoid response relative to the PHA response could derive simply from a smaller responding cell precursor frequency in the former, as has been shown in other systems (52), even though suboptimal concentrations of PHA and optimal concentrations of tetanus toxoid were used in the cultures. Thus, a common inhibitory influence might exist in both the nonspecific mitogen response and the specific antigenic response, with greater activity on the latter because the number of responding cells is smaller. Perhaps favoring such a common mechanism was the similar efficiency of tetanus toxoid- and PHA-induced $T$ cell blasts to absorb antibody inhibiting the tetanus toxoid response. Furthermore, regression analysis revealed a significant association between inhibition of the two responses by the SLE sera.

It is interesting that the early phase inhibitory activity of SLE anti-T cell blast antibodies reduced the initial expression 
of IL-2 receptors (Tac+ cells) and markedly attenuated the proliferative response of cultures to additional exogenous IL-2. (Although not approached in this study, the production of IL-2 was probably reduced as well.) The inhibition kinetics here are consistent with interaction of SLE antibody with T cell receptors for antigen or class II molecules (53-55), or with IL-2 receptors. Other potential mechanisms requiring further investigation include antibodies to isotypic or clonotypic determinants of the $T$ cell antigen receptor; antibodies to IL-2, although this is unlikely; and antibodies that deliver an off signal analogous to that shown with OKT11 (56).

Our studies concerning the specificity of anti-T blast antibodies provided no evidence for blockade or modulation of the T3, T4, or Tac molecules but were indirect and subject to alternate interpretations. Crucial to the clarification of this issue are experiments to characterize directly the reactive antigen(s) by immunoprecipitation or immunoblotting procedures. Preliminary Western blot data from our laboratory show that SLE antibodies that inhibit the tetanus toxoid response detect several surface membrane molecules on activated $\mathrm{T}$ cells that are not apparent on resting gels (unpublished observations). The most prominent of these have approximate molecular weights of 56,000,51,000 and 32,000. Others recently have identified SLE antibody-reactive glycoproteins by immunoprecipitation with molecular weights of 42,000 and 66,000 on PHA activated peripheral $T$ cells and an adult $T$ cell leukemia line (57). These proteins appear to be identical with the IL-2 receptor, a finding obviously relevant to the present functional observations.

Despite uncertainty about the exact specificity of the antibodies involved, the present observations provide insight into mechanisms underlying certain aspects of immunologic dysfunction in SLE. First, a depressed proliferative response of $T$ cells to soluble antigens and a variety of other specific and nonspecific stimuli is characteristic of cells isolated from patients with this disorder (1-4). Our data indicate that such abnormal function can be reproduced, at least with respect to the tetanus toxoid system, in normal lymphocytes through effects of a novel type of antibody to activated T cells. Since most previous investigations have considered only those antibodies that are reactive with resting $T$ cells, the present findings provide an explanation for the failure to define a clear relationship between abnormal cell function and antilymphocyte antibodies to resting $T$ cells $(21,27)$.

Because antilymphocyte antibodies in SLE can mediate cell killing in the absence of complement $(58,59)$ or modulate the expression of surface receptors at physiologic temperatures (21) with consequent alteration in lymphocyte function, lymphocyte/antilymphocyte antibody interactions of the type described here probably occur in vivo. Such in vivo autoantibody effects on circulating lymphocytes in SLE could carry over to in vitro experiments even in the absence of persisting antibody and thereby influence putatively intrinsic lymphocyte functional properties. Relevant examples of this include defective production of IL-2 (60) and decreased proliferative response to tetanus toxoid of $\mathrm{T}$ cells from patients with SLE (2). Of even greater interest is the idea that auto-antibodies to $T$ cells in this disorder are fundamentally important in pathogenesis, as suggested by their association with lymphopenia (61), with a variety of $T$ cell functional abnormalities, and with active disease. It will be especially challenging in future studies to determine whether antibodies with the functional effects on $T$ cell activation demonstrated herein reflect an exaggerated homeostatic regulatory mechanism in response to ongoing autoimmune reactions, or play a causal role in the underlying pathogenesis of SLE and related disorders.

\section{Acknowledgments}

We give special appreciation to the late Dr. Henry G. Kunkel for certain pivotal ideas that stimulated this investigation. The technical assistance of Melody Shaw and Rekha Shah is gratefully acknowledged. We also thank Dr. Philip Cohen and Dr. Robert Eisenberg for advice and criticism, and Cathy Miller-Wells and Aretha Jones for typing the manuscript.

This research was supported in part by National Institutes of Health grant R0-1 AM 30863, the University of North Carolina Multipurpose Arthritis Center, and an Arthritis Foundation Clinical Research Center grant.

\section{References}

1. Rosenthal, C. J., and E. C. Franklin. 1975. Depression of cellular-mediated immunity in systemic lupus erythematosus. Arthritis Rheum. 18:207-217.

2. Gottlieb, A. B., R. G. Lahita, N. Chiorazzi, and H. G. Kunkel. 1979. Immune function in systemic lupus erythematosus. Impairment of in vitro $\mathrm{T}$ cell proliferation and in vivo antibody response to exogenous antigen. J. Clin. Invest. 63:885-892.

3. Sakane, T., A. D. Steinberg, and I. Green. 1978. Failure of autologous mixed lymphocyte reactions between $T$ and non- $T$ cells in patients with systemic lupus erythematosus. Proc. Natl. Acad. Sci. USA. 75:3464-3468.

4. Horwitz, D. A., M. A. Garrett, and A. H. Craig. 1977. Serum effects on mitogenic reactivity in subjects with systemic lupus erythematosus, rheumatoid arthritis, and scleroderma. Technical considerations and lack of correlation with anti-lymphocyte antibodies. Clin. Exp. Immunol. 27:100-110.

5. Karsh, J., G. Dorval, and C. K. Osterland. 1981. Natural cytotoxicity in rheumatoid arthritis and systemic lupus erythematosus. Clin. Immunol. Immunopathol. 19:437-446.

6. Silverman, S. L., and E. S. Cathcort. 1980. Natural killing in systemic lupus erythematosus: inhibitory effects of serum. Clin. Immunopathol. 17:219-226.

7. Scheinberg, M. A., and E. S. Cathcart. 1976. Antibody-dependent direct cytotoxicity of human lymphocytes. I. Studies on peripheral blood lymphocytes and sera of patients with systemic lupus erythematosus. Clin. Exp. Immunol. 24:317-322.

8. Schneider, J., W. Chin, G. J. Friou, S. M. Cooper, B. Harding, R. L. Hill, and F. P. Quismorio. 1975. Reduced antibody-dependent cell-mediated cytotoxicity in systemic lupus erythematosus. Clin. Exp. Immunol. 20:187-192.

9. Charpentier, B., C. Carnaud, and J. F. Bach. 1979. Selective 
depression of xenogeneic cell-mediated lympholysis in systemic lupus erythematosus. J. Clin. Invest. 64:351-360.

10. Tsokos, G. C., and J. E. Balow. 1981. Cytotoxic responses to alloantigens in systemic lupus erythematosus. J. Clin. Immunol. 1:208216.

11. Bresnihan, B., and H. E. Jasin. 1977. Suppressor function of peripheral blood mononuclear cells in normal individuals and in patients with systemic lupus erythematosus. J. Clin. Invest. 59:106116.

12. Fauci, A. S., A. D. Steinberg, B. F. Haynes, and G. Whalen. 1978. Immunoregulatory aberrations in systemic lupus erythematosus. J. Immunol. 121:1473-1479.

13. Sakane, T., A. D. Steinberg, and I. Green. 1978. Studies of immune functions of patients with systemic lupus erythematosus. I. Dysfunction of suppressor T-cell activity related to impaired generation of, rather than response to, suppressor cells. Arthritis Rheum. 21:657664.

14. Sakane, T., H. Kotani, S. Takada, Y. Murakawa, and Y. Ueda. 1983. A defect in the suppressor circuits among OKT4+ cell populations in patients with systemic lupus erythematosus occurs independently of a defect in the OKT8+ suppressor $\mathrm{T}$ cell function. J. Immunol. 131:753-761.

15. Morimoto, C., E. L. Reinherz, J. A. Distaso, A. D. Steinberg, and S. F. Schlossman. 1984. Relationship between systemic lupus erythematosus $\mathrm{T}$ cell subsets, anti-T cell antibodies, and $\mathrm{T}$ cell functions. J. Clin. Invest. 73:689-700.

16. Jasin, H. E., and M. Ziff. 1975. Immunoglobulin synthesis by peripheral blood cells in systemic lupus erythematosus. Arthritis Rheum. 18:219-228.

17. Budman, D. R., E. B. Merchant, A. D. Steinberg, B. Doft, M. E. Gershwin, E. Lizzio, and J. P. Reeves. 1977. Increased spontaneous activity of antibody-forming cells in the peripheral blood of patients with active SLE. Arthritis Rheum. 20:829-833.

18. Ginsburg, W. W., F. D. Finkelman, and P. E. Lipsky. 1979. Circulating and pokeweed mitogen-induced immunoglobulin-secreting cells in systemic lupus erythematosus. Clin. Exp. Immunol. 35:76-88.

19. Yu, D. T. Y., R. J. Winchester, S. M. Fu, A. Gibofsky, H. S. Ko, and H. G. Kunkel. 1980. Peripheral blood Ia-positive T cells. Increases in certain diseases and after immunization. J. Exp. Med. 151:91-100.

20. Cohen, P. L., D. A. Litvin, and J. B. Winfield. 1982. Association between endogenously activated $T$ cells and immunoglobulin-secreting B cells in patients with active systemic lupus erythematosus. Arthritis Rheum. 25:168-173.

21. Wernet, P., and H. G. Kunkel. 1973. Antibodies to a specific surface antigen on $\mathrm{T}$ cells in human sera inhibiting mixed leukocyte culture reactions. J. Exp. Med. 138:1021-1026.

22. Winfield, J. B. 1984. Anti-lymphocyte antibodies in SLE. Specificity and relationship to abnormal cellular function. In Systemic Lupus Erythematosus. R. Lahita, editor. John Wiley \& Sons, New York. In press.

23. Sakane, T., A. D. Steinberg, J. P. Reeves, and I. Green. 1979. Studies of immune functions of patients with systemic lupus erythematosus. Complement-dependent immunoglobulin $\mathbf{M}$ anti-thymusderived cell antibodies preferentially inactivate suppressor cells. J. Clin. Invest. 63:954-965.

24. Sagawa, A., and N. I. Abdou. 1979. Suppressor-cell antibody in systemic lupus erythematosus. Possible mechanism for suppressorcell dysfunction. J. Clin. Invest. 63:536-539.

25. Glinski, W., M. E. Gershwin, and A. D. Steinberg. 1976
Fractionation of cells on a discontinuous Ficoll gradient. Study of subpopulations of human $T$ cells using anti-T cell antibodies from patients with systemic lupus erythematosus. J. Clin. Invest. 57:604614.

26. Sakane, T., A. D. Steinberg, J. P. Reeves, and I. Green. 1979. Studies of immune functions of patients with systemic lupus erythematosus. $\mathrm{T}$ cell subsets and antibodies to $\mathrm{T}$ cell subsets. J. Clin. Invest. 64:1260-1269.

27. Horwitz, D. A., and J. B. Cousar. 1975. A relationship between impaired cellular immunity, humoral suppression of lymphocytes and severity of systemic lupus erythematosus. Am. J. Med. 58:829-835.

28. Winfield, J. B., R. J. Winchester, P. Wernet, S. M. Fu, and H. G. Kunkel. 1975. Nature of cold-reactive antibodies to lymphocyte surface determinants in systemic lupus erythematosus. Arthritis Rheum. 18:1-8.

29. Williams, R. C., Jr., A. D. Bankhurst, and J. D. Montano. 1976. IgG anti-lymphocyte antibodies in SLE detected by ${ }^{125}$ I-protein A. Arthritis Rheum. 19:1261-1270.

30. Okudaira, K., R. P. Searles, J. L. Ceuppens, J. S. Goodwin, and R. C. Williams, Jr. 1982. Anti-Ia reactivity in sera from patients with systemic lupus erythematosus. J. Clin. Invest. 69:17-24.

31. Litvin, D. A., P. L. Cohen, and J. B. Winfield. 1983. Characterization of warm-reactive IgG anti-lymphocyte antibodies in systemic lupus erythematosus. Relative specificity for mitogen-activated $\mathrm{T}$ cells and their soluble products. J. Immunol. 130:181-186.

32. Tan, E. M., A. S. Cohen, J. F. Fries, A. T. Masi, D. J. McShane, N. F. Rothfield, J. G. Schaller, N. Talal, and R. F. Winchester. 1982. The 1982 revised criteria for the classification of systemic lupus erythematosus. Arthritis Rheum. 25:1271-1277.

33. Winfield, J. B., C. M. Brunner, J. S. Davis IV, and W. M. O'Brien. 1972. Assessment of disease activity in systemic lupus erythematosus (SLE). Arthritis Rheum. 15:462. (Abstr.)

34. Geha, R. S., H. Milgrom, M. Broff, S. Alpert, S. Martin, and E. J. Yunis. 1979. Effect of anti-HLA antisera on macrophage-T-cell interaction. Proc. Natl. Acad. Sci. USA. 76:4038-4041.

35. Julius, M. H., E. Simpson, and L. A. Herzenberg. 1973. A rapid method for isolation of functional thymus-derived murine lymphocytes. Eur. J. Immunol. 3:645-649.

36. Nardiello, S., P. Pizzella, M. Russo, and B. Galanti. 1982. Esterase staining of monocytes in suspensions of Ficoll-Hypaque isolated mononucler cells. J. Immunol. Methods. 52:111-114.

37. Winfield, J. B., R. J. Winchester, P. Wernet, and H. G. Kunkel. 1975. Specific concentrations of anti-lymphocyte antibodies in the serum cryoprecipitates of patients with systemic lupus erythematosus. Clin. Exp. Immunol. 19:399-406.

38. Stocker, J. W., G. Garotta, B. Hausmann, M. Trucco, and R. Ceppellini. 1979. Separation of human cells bearing HLA-DR antigens using a monoclonal antibody rosetting method. Tissue Antigens 13:212222.

39. Goding, J. W. 1976. The chromic chloride method of coupling antigens to erythrocytes: definition of some important parameters. $J$. Immunol. Methods. 10:61-66.

40. Lampon, L. A., and R. Levy. 1980. Two populations of Ia-like molecules on a human B cell line. J. Immunol. 125:293-299.

41. Miyawaki, T., A. Yachie, N. Uwadana, S. Ohzeki, T. Nagaoki, and N. Taniguchi. 1982. Functional significance of Tac antigen expressed on activated human $\mathrm{T}$ lymphocytes: Tac antigen interacts with $\mathrm{T}$ cell growth factor in cellular proliferation. J. Immunol. 129:2474-2478.

42. Okudaira, K., R. P. Searles, J. S. Goodwin, and R. C. Williams, Jr. 1982. Antibodies in the sera of patients with systemic lupus 
erythematosus that block the binding of monoclonal anti-la to Ia-positive targets also inhibit the autologous mixed lymphocyte response. J. Immunol. 129:582-586.

42a. Yamada, A., M. Shaw, and J. B. Winfield. Surface antigen specificity of anti-lymphocyte autoantibodies in systemic lupus erythematosus (SLE). Arthritis Rheum. In press.

43. Hirschberg, H., T. Hirschberg, H. Nousioinen, L. R. Braether, and E. Jaffe. 1982. The effects of corticosteroids on the antigen presenting properties of human monocytes and endothelial cells. Clin. Immunol. Immunopathol. 23:577-585.

44. Saxon, A., and E. Barnett. 1984. Human auto-antiidiotypes regulating T cell-mediated reactivity to tetanus toxoid. J. Clin. Invest. 73:342-348.

45. Searles, R. P., R. P. Messner, and S. M. Hermanson. 1981. Anti-lymphocyte antibodies in theumatoid arthritis: increased reactivity against activated lymphocytes. Clin. Immunol. Immunopathol. 20:246254.

46. Winfield, J. B., P. I. Lobo, and A. Singer. 1978. Significance of anti-lymphocyte antibodies in systemic lupus erythematosus. Arthritis Rheum. 21:S215-S221.

47. DeFreitas, E. C., R. W. Chesnut, H. M. Grey, and J. M. Chiller. 1983. Macrophage-dependent activation of antigen-specific $T$ cells requires antigen and a soluble monokine. J. Immunol. 131:23-29.

48. Lipkowitz, S., W. C. Greene, A. L. Rubin, A. Novogrodsky, and K. H. Stenzel. 1984. Expression of receptors for interleukin-2: role in the commitment of $\mathrm{T}$ lymphocytes to proliferate. J. Immunol. 132:31-37.

49. Gunther, G. R., J. L. Wang, and G. M. Edelman. 1974. The kinetics of cellular commitment during stimulation of lymphocytes by lectins. J. Cell Biol. 62:366-377.

50. Unanue, E. R., D. I. Beller, C. Y. Lu, and P. M. Allen. 1984. Antigen presentation: comments on its regulation and mechanism. $J$. Immunol. 132:1-5.

51. Qvigstad, E., and E. Thorsby. 1983. Class-II HLA restriction of antigen-specific human T-lymphocyte clones. Evidence of restriction elements on both DR and MT molecules. Scand. J. Immunol. 18:299306.
52. Lane, H. C., G. Whalen, and A. S. Fauci. 1983. Antigeninduced human $T$ cell help. Precursor frequency, radiation sensitivity, and allogeneic effects. J. Clin. Invest. 72:636-647.

53. Biddison, W. E., P. E. Rao, M. A. Talle, G. Goldstein, and S. Shaw. 1983. Possible involvement of the $T 4$ molecule in $T$ cell recognition of class II HLA antigens: evidence from studies of proliferative responses to SB antigens. J. Immunol. 131:152-157.

54. Chang, T. W., P. C. Kung, S. P. Gingras, and G. Goldstein. 1981. Does OKT3 monoclonal antibody react with an antigen-recognization structure on human T cells? Proc. Natl. Acad. Sci. USA. 78:1805-1808.

55. Reinherz, E. L., R. E. Hussey, and S. F. Schlossman. 1980. A monoclonal antibody blocking human T cell function. Eur. J. Immunol. 10:758-762.

56. Palacios, R., and O. Martinez-Maza. 1982. Is the E receptor on human T lymphocyte a "negative signal" receptor? J. Immunol. 129:2479-2485.

57. Kagami, M., T. Koike, H. Tomioka, and S. Yoshida. 1984. IgG anti-lymphocyte autoantibody specific for an adult $\mathrm{T}$ cell leukemia cell line and activated lymphocytes in sera from patients with SLE. Arthritis Rheum. 27:S83. (Abstr.)

58. Kumagai, S., A. D. Steinberg, and I. Green. 1981. Antibodies to $T$ cells in patients with systemic lupus erythematosus can induce antibody-dependent cell-mediated cytotoxicity against human $\mathrm{T}$ cells. J. Clin. Invest. 67:605-614.

59. Okudaira, K., R. P. Searles, K. Tanimoto, Y. Horiuchi, and R. C. Williams, Jr. 1982. T lymphocyte interaction with immunoglobulin $\mathbf{G}$ antibody in systemic lupus erythematosus. J. Clin. Invest. 69:1026-1038.

60. Linker-Israeli, M., A. L. Bakke, R. C. Kitridou, S. Gendler, S. Gillis, and D. A. Horwitz. 1983. Defective production of interleukin 1 and interleukin 2 in patients with systemic lupus erythematosus (SLE). J. Immunol. 130:2651-2655.

61. Winfield, J. B., R. J. Winchester, and H. G. Kunkel. 1975. Association of cold-reactive antilymphocyte antibodies with lymphopenia in systemic lupus erythematosus. Arthritis Rheum. 18:587-594. 